\title{
Impacts of food-based enrichment on behaviour and physiology of male greater rheas (Rhea Americana, Rheidae, Aves)
}

\author{
Márcia Fontes Figueiredo Lima ${ }^{1,4}$; Cristiano Schetini de Azevedo ${ }^{1,5}$; Robert John Young ${ }^{2}$ \& Priscila Viau ${ }^{3}$
}

${ }^{1}$ Universidade Federal de Ouro Preto (UFOP), Instituto de Ciências Exatas e Biológicas (ICEB), Departamento de Biodiversidade, Evolução e Meio Ambiente (DEBIO), Laboratório de Zoologia dos Vertebrados. Ouro Preto, MG, Brasil.

${ }^{2}$ University of Salford, Manchester. Manchester, United Kingdom. ORCID: http://orcid.org/0000-0002-8407-2348. E-mail: r.j.young@salford.ac.uk

${ }^{3}$ Universidade de São Paulo (USP), Faculdade de Medicina Veterinária e Zootecnia (FMVZ), Hospital Veterinário (HOVET), Laboratório de Dosagens Hormonais (LDH). São Paulo, SP, Brasil. ORCID: http://orcid.org/0000-0002-5138-3676. E-mail: priviau@usp.br

${ }^{4}$ ORCID: http://orcid.org/0000-0003-1205-3735. E-mail:marciafflima@yaho0.com.br

${ }^{5}$ ORCID: http://orcid.org/0000-0003-0256-9017. E-mail: cristianoroxette@yaho0.com (corresponding author).

\begin{abstract}
Distress can be defined as a biological response of an individual to long-term threats to its homeostasis and it should be avoided from an animal welfare perspective. High levels of stress hormones and the expression of abnormal behaviours are responses normally observed in distressed animals. Captive environments can provoke distress, especially when inappropriate stimuli are provided to the animals. The concomitant use of behavioural and non-invasive hormonal measures is a means to evaluate captive animal welfare. Environmental enrichment is a tool that can reduce distress and minimize the expression of abnormal behaviour in captive animals. The aim of this study was to evaluate greater rheas' responses (behavioral and hormonal) to food-based enrichment. Three birds from the Belo Horizonte Zoo, Brazil were studied. The study was divided into three phases (baseline, enrichment and post-enrichment): fruits scattered around the birds' enclosure were used as enrichment. Behaviour and faecal sampling were undertaken in all phases of the study. Abnormal behaviours and faecal glucocorticoid metabolites (GCM) levels showed significant reduction during the environmental enrichment phase, and a significative positive correlation between GCM production and abnormal pacing was observed. From the results of this study, we conclude that the use of food as environmental enrichment should be encouraged because of its positive effects on animal welfare. Besides, studies with larger groups of greater rheas, with individuals of both sexes, should also be encouraged to evaluate if the results found in this pilot study are consistent and can be generalized to the species.
\end{abstract}

Key-Words. Abnormal behaviours; Environmental enrichment; Rhea; Stress; Zoo animal welfare.

\section{INTRODUCTION}

A restricted or unstimulating environment increases the probability that an animal will develop abnormal behaviour (Kelling \& Jensen, 2009). Animals that exhibit abnormal behaviour normally have a lower level of welfare and frequently higher levels of stress (Young, 2003; Broom \& Molento, 2004). Thus, reducing deleterious effects of long term stress (i.e., distress) becomes essential for animal welfare, since animals that experience a high welfare level express more normal behaviour, have better health, less reproductive failure and normal cognitive abilities (Moberg \& Mench, 2000). Concomitant use of non-invasive behavioural and hormonal measures is a way to assess animal wel- fare, since behavioural changes exhibited by animals do not always indicate changes in levels of stress hormones (Vincent \& Michell, 1992; Redbo, 1993; Salak-Johnson et al., 1997).

Environmental enrichment is a set of techniques designed to improve the quality of life of animals kept in captivity, seeking to identify and provide the necessary environmental stimuli for their physical and psychological welfare (Shepherdson et al., 1998; Young, 2003). Foodbased enrichment has been proven to be effective in stimulating animals and reducing distress, because the acquisition of food is a highly-motivated behaviour and is self-rewarding (Young, 2003; Vasconcellos et al., 2009; Clark \& Melfi, 2012; Azevedo et al., 2013a). 
The greater rhea, Rhea americana (Struthioniformes, Rheidae) is considered the largest bird of South America (Sick, 1997). Greater rheas spend much of their time walking and foraging in the wild (Azevedo et al., 2010), and are considered omnivorous birds, feeding on seeds, fruits, leaves, insects and small vertebrates (Dani, 1993; Renison et al., 2010; Azevedo et al., 2013b). The greater rhea is considered near threatened with extinction globally (IUCN, 2018).

Greater rheas have been farmed since 1990s in American and European countries (Navarro \& Martela, 2002). This species adapts well to captive environments, showing high rates of egg production and chick survival when good management techniques are employed (Silva, 2001; Navarro \& Martella, 2002; Hosken \& Silveira, 2003). However, if the birds are distressed, then their productivity may lower (Silva, 2001; Gebregeziabhear \& Ameha, 2015). The main welfare problems of captive greater rheas are physical injuries due to claw abrasion during fights, feather pecking, respiratory infections caused by microrganisms, fungal, bacterial, protozoan and viral deseases, nutritional problems and abnormal repetitive behaviours such as pacing (Cubas et al., 2007; Glatz et al., 2011). Thus, understanding the effects of environmental enrichment on the behavior and physiology of greater rheas can improve not only their welfare, but also their productivity, helping both the conservation and the production of these birds.

While some published studies evaluated the behaviour of greater rheas (Azevedo \& Young, 2006; Azevedo et al., 2010, 2012a, b - antipredator responses, time-activity budget in nature, visitor influence on the behaviour, and predator discrimination, respectively; Della Costa et al., 2013 - behaviour after transportation), others have conducted hormonal analysis of this species (Lèche et al., 2009, 2011, 2013 - ACTH challenge, use of faeces to evaluate stress hormones, and stress during transportation, respectively); however, no study has simultaneously used both methodologies concurrently (behaviour and hormone) to evaluate greater rhea welfare. We aimed to run a pilot study to evaluate how the behavioural repertoire of zoo-housed greater rhea varies with their distress levels as measured from faecal hormone metabolites.

\section{MATERIAL AND METHODS}

\section{Study area, housing and maintenance}

The pilot study was conducted with three male greater rheas held by Belo Horizonte Zoo, Brazil (S 1951', W $\left.44^{\circ} 01^{\prime}\right)$ : hereafter $\mathrm{BH}$ Zoo. The mean annual temperature varies between $18^{\circ} \mathrm{C}$ and $24^{\circ} \mathrm{C}$, and the annual pluviometric mean of $1,460 \mathrm{~mm}$, with two distinct seasons: a dry season from April to September and a rainy season from October to March, being the climate classified as Aw in the Köeppen system (Reboita et al., 2015). Birds were exposed to visitors six days a week (Tuesday to Sunday). All birds were born at the zoo and aged between 10 and
15 years. The rheas were fed twice a day at 09:00 $\mathrm{h}$ and 14:00 $\mathrm{h}$ with a mixture of food for ratites (Socil ${ }^{\oplus}, 1.2 \mathrm{~kg}$ ) and vegetables (cabbage, carrot, beetroot). Throughout the study, greater rheas had access to water ad libitum. The enclosure measured $1,021 \mathrm{~m}^{2}$, had a soil substrate with a great variety of trees, and it was cleaned once each day, in the mornings.

\section{Environmental enrichment}

The type of enrichment chosen for this study was a mixture of chopped fruits ( $2.5 \mathrm{~kg}$ of apple, banana, papaya and pear per day per group), which were scattered through the enclosure. During enrichment use (enrichment phase), the same quantities of the normal diet continued to be offered to the birds in the feeder. Enrichment items were chosen based on Azevedo et al. (2013a), which showed that new palatable food items are rewarding for greater rheas. The study was divided into three phases of $30 \mathrm{~h}$ : baseline (birds with no enrichment), enrichment (when the enrichment items were available to the birds) and post-enrichment (birds with no enrichment, when conditions returned to those of the baseline) (Young, 2003). The enrichment was provided immediately before starting behavioural data collection, once a day (08:00 h or 13:00 h).

Table 1. Ethogram of the greater rheas (Rhea americana, Rheidae, Aves) at $\mathrm{BH} \mathrm{ZOO}$.

\begin{tabular}{|c|c|c|}
\hline Behavioural category & Behaviour & Description \\
\hline \multirow[t]{2}{*}{ Vigilance } & Alert & The rhea stands still with neck up high. \\
\hline & Walking alert & The rhea walks with neck up high. \\
\hline \multirow[t]{3}{*}{ Activity } & Walking & $\begin{array}{l}\text { The rhea walks slowly through the enclosure, } \\
\text { not in an alert posture. }\end{array}$ \\
\hline & Running & $\begin{array}{l}\text { The rhea runs in zigzags or straight through } \\
\text { its enclosure. }\end{array}$ \\
\hline & Pecking & $\begin{array}{l}\text { The rhea pecks objects such as the fence or } \\
\text { stones. }\end{array}$ \\
\hline Inactivity & Inactive & $\begin{array}{l}\text { The rhea assumes a standing, crouching, } \\
\text { sitting or sleeping posture, with no } \\
\text { movements. }\end{array}$ \\
\hline \multirow[t]{3}{*}{ Nourishment } & Foraging & $\begin{array}{l}\text { The rhea walks while pecking and ingesting } \\
\text { items from the ground. }\end{array}$ \\
\hline & Eating & The rhea eats food from its feeder. \\
\hline & Drinking water & The rhea drinks water from its water hole. \\
\hline \multirow[t]{3}{*}{ Maintenance } & Preening & The rhea preens feathers with its beak. \\
\hline & Dust bathing & $\begin{array}{l}\text { The rhea lies down and throws soil over its } \\
\text { body using its beak. }\end{array}$ \\
\hline & Defecating/urinating & The rhea defecates or urinates. \\
\hline \multirow[t]{3}{*}{ Abnormal behaviours } & Eating faeces & The rhea ingests faeces. \\
\hline & Pacing & $\begin{array}{l}\text { The rhea walks from one side of the enclosure } \\
\text { to the other, using the same route and with } \\
\text { no apparent reason. }\end{array}$ \\
\hline & Escaping behaviour & $\begin{array}{l}\text { The rhea jumps and then run in zigzags as } \\
\text { soon as feet touch the ground. }\end{array}$ \\
\hline \multirow[t]{2}{*}{ Aggression } & Fighting & The rhea fights with each other. \\
\hline & Attacking keeper & The rhea attacks the keeper. \\
\hline Not visible & Not visible & The rhea is out of sight. \\
\hline Other behaviours & Other behaviours & $\begin{array}{l}\text { The rhea exhibits behaviours not in the } \\
\text { above list. }\end{array}$ \\
\hline
\end{tabular}




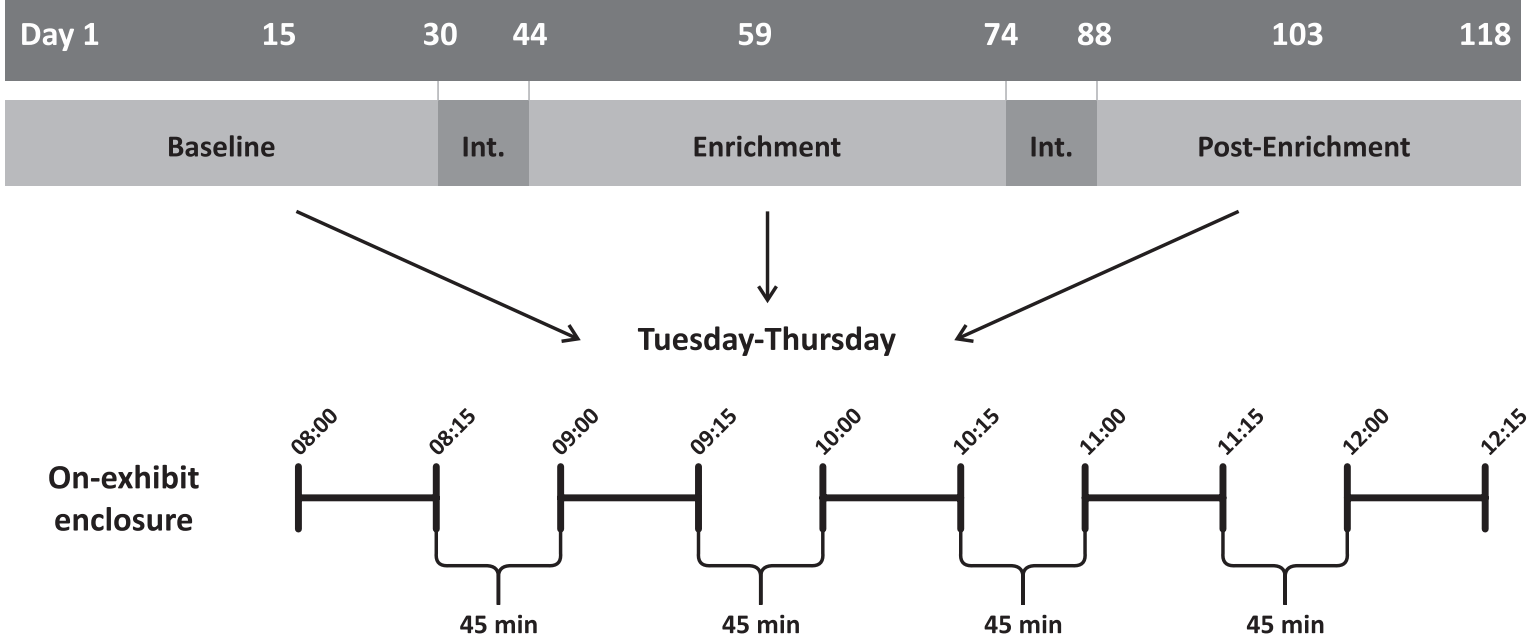

Monday-Wednesday-Friday

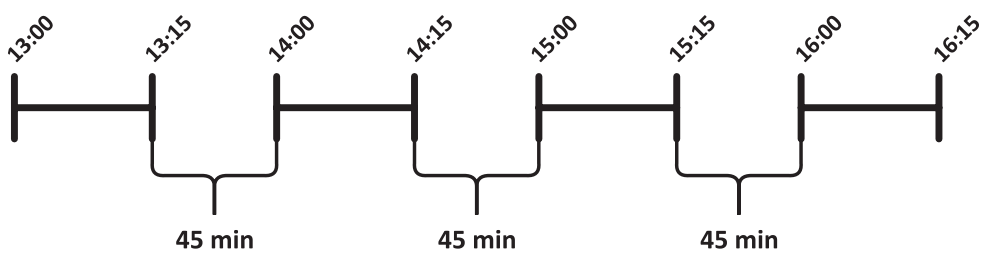

Figure 1. Graphic timeline for the recording of behavioural and physiological data of greater rheas. Each phase lasted 30 days, with intervals of 14 days among phases. Behavioural and physiological data occurred concomitantly. In this timeline, it is represented data collection that occurred on Tuesdays and Thursdays. In Mondays, Wednesdays and Fridays, data collection occurred from 13:00 $\mathrm{h}$ to 16:15 $\mathrm{h}$. Enrichment was provided at 08:00 or 13:00 $\mathrm{h}$, depending on the day of the week.

\section{Behavioural data}

Behavioural data were collected by the same person during the three experimental phases, using scan sampling with instantaneous recording of behaviours every 30 seconds (Altmann, 1974). The hours of data collection were divided as follows: Mondays, Wednesdays and Fridays from 13:00 h to 16:15 h; Tuesdays and Thursdays from $08: 00 \mathrm{~h}$ to $12: 15 \mathrm{~h}$ (Fig. 1). Thus, data were collected for $1 \mathrm{hr} /$ day. Each phase of the study lasted 30 days, totaling 90 days of data collection and 60 hours in each phase. Data were collected from August 2013 to January 2014, with intervals of two weeks between phases. During the intervals, rheas' management was the same without environmental enrichment items.

The ethogram used in the research is shown in Table 1. Pacing and eating faeces were considered abnormal behaviours and greater rheas at the $\mathrm{BH}$ Zoo have exhibited these behaviours since 2004, when these individuals were first studied systematically (Azevedo \& Young, 2006). Pacing was defined as rheas performing three back and forth movements (walking) on the same route.

\section{Physiological data}

Faecal glucocorticoid immunoreactive metabolities (GCM) were assessed to evaluate stress hormone levels (Lèche et al., 2011).

\section{Faecal samples}

Faeces were collected in all phases of the study. A total of 90 faecal samples were collected (30 samples at baseline, 30 samples at enrichment and 30 samples at post-enrichment). Faecal collection was always conducted at the same time at 07:30 $\mathrm{h}$ because concentrations of glucocorticoid immunoreactive metabolites can vary across the day (Touma \& Palme, 2005). Using gloves and a plastic spoon, pasty and central portions of the faecal mass were collected (an average of $30 \mathrm{~g}$ ), homogenized (vegetable pieces or undigested food items were removed), placed in ziploc plastic bags and put in $\mathrm{a}-30^{\circ} \mathrm{C}$ freezer in the Veterinary Sector of the $\mathrm{BH}$ Zoo. At the end of the study, 90 samples of frozen faeces were sent in a Styrofoam box chilled with dry ice to the Laboratory of Vertebrate Zoology at Federal University of Ouro Preto where the hormone extraction procedure was performed. Due to the characteristics of the faecal matter, it was not possible to identify the provinence of individual faeces. Hence, each sample was composed of a mixture of three individual samples (faecal groups) for each day.

\section{Hormonal extraction}

The methodology used for the extraction of faecal immunoreactive metabolites was that described by Brown et al. (1996), Möstl \& Palme (2009), and Palme 
et al. (2013). Five milliliters of methanol (Merck $\left.{ }^{\circledR}\right) 60 \%$ (60\% methanol, $40 \%$ distilled water) were added to an aliquot of $0.5 \mathrm{~g}$ of wet faeces. After vortex (Fisher Vortex) homogenization for one minute, the samples were left 16 hours overnight in a homogenizer (Homogenizer Benfer, BHS_300). Then, the samples were centrifuged for 15 minutes at 3,500 g (CentriBio) and the supernatant was moved to Eppendorf tubes. Tubes were stored in the freezer of the Laboratory of Vertebrate Zoology and were sent to the Laboratory of Hormonal Dosage of the School of Veterinary Medicine and Animal Science of University of São Paulo (USP) to calculate hormonal dosages using radioimmunoassay.

\section{Radioimmunoassay}

To measure the faecal hormonal metabolites, RIA Corticosterone $\mathrm{I}^{125}$ double antibody ImmuChem $^{\mathrm{TM}}$ kits (MP Biomedicals, LLC., Orangeburg, NY, USA) were used; this uses iodine-125 $\left(\mathrm{I}^{125}\right)$ as a tracer element. Procedures carried out for the dosage of the hormone followed the kit's protocol. Hormonal quantification was performed in a gamma counter (Packard Cobra Auto-Gamma ${ }^{\mathrm{TM}}$ ): sampling the number of counts per minute. The results were provided in nanograms per milliliter $(\mathrm{ng} / \mathrm{ml})$, as predetermined by the group diagnostic protocol. The final values of corticosterone immunoreactive metabolites were corrected for weight and dilution and expressed in nanograms per gram of wet faeces ( $\mathrm{ng} / \mathrm{g}$ ), and finally converted into micrograms per gram of wet faeces (ug/g) (Viau, 2003; Berbare, 2004).

Parallelism and precision tests, already conducted in another study, validated the corticosterone RIA kit I ${ }^{125}$ for hormonal analysis of rhea faeces (Lèche et al., 2011), and therefore were not repeated in this experiment.

\section{Statistical analysis}

The behavioural and hormonal results of all phases of the study were analyzed using Friedman's non-parametrical ANOVA test. The Dunn's test was used post-hoc to compare significant responses between phases. A Spearman rank correlation test was used to analyze if the production (i.e., concentration) of faecal glucocorticoid immunoreactive metabolities was correlated with the exhibition normal and abnormal behaviours (Zar, 2010). General Linear Models (GLM) were used to verify the influence of the time of sampling on the efficiency of measuring the effects of enrichment efficiency, using as an explanatory variable the data collection time and as response variables the behaviours exhibited by greater rheas. For significant results, we used a contrasting analysis (Coms) to find out whether sampling time influenced behaviour. For all statistical analyses, the confidence level was 95\% $(a=0.05)$. Tests were run using R 3.4.2 and Minitab 16 softwares.

\section{RESULTS}

\section{Behaviour}

Greater rheas showed significant differences in walking, foraging, eating faeces and pacing behaviours. Walking increased significantly from baseline to enrichment phase, increasing a little more in the post-enrichment phase (Fig. 2). Foraging was highest during the enrichment phase (Fig. 2). Abnormal behaviours eating faeces and pacing showed the same responses for the environmental enrichment phase: both decreased significantly from the baseline to the enrichment phase; eating faeces showed a slight increase in post-enrichment phase and pacing continued to decrease during post-enrichment phase (Fig. 2). All other behaviours performed by the greater rheas are shown in Table 2.

Walking, alert, walking alert, inactive and foraging behaviours were influenced by the time of data sampling, being most exhibited during placement of environmental enrichment (08:00 $\mathrm{h}$ and 13:00 $\mathrm{h}$ ) and decreasing in hours more distant from the introduction of enrichment. Inactive was most exhibited from 11:00 h to 12:00 h. The abnormal behaviours eating faeces and pacing were not influenced by data sampling time (eating faeces: $F=0.52$, $\mathrm{P}=0.84$; pacing: $\mathrm{F}=1.17, \mathrm{P}=0.32 ; \mathrm{N}=132, \mathrm{df}=8$ for both behaviours).

\section{Physiology}

Faecal glucocorticoid immunoreactive metabolite concentrations decreased significantly during the enrichment phase, and remained low even after its withdrawal (Fig. 3).

A positive correlation was observed between the expression of pacing and the production of GCM in the enrichment phase in greater rheas; that is, the more faecal glucocorticoid immunoreactive metabolites were produced, the greater the expression of pacing behaviour (Fig. 4). No other behaviour was significantly correlated to the expression of GCM in any of the phases.

\section{DISCUSSION}

Environmental enrichment decreased the exhibition of abnormal behaviour by male greater rheas and increased activity levels. Beyond this, the use of environmental enrichment was associated with a decrease in the concentration of stress hormones, thereby probably improving the welfare of the captive male rheas.

Male greater rheas walked, walked alert, stood alert, and foraged more after the provision of environmental enrichment and decreased the exhibition of abnormal behaviours; the same result has been observed in other studies with ratites and other birds (Meehan et al., 2003, 2004; Christensen \& Nielsen, 2004; Dias et al., 2011; Azevedo et al., 2013a). In all of these studies, 
Table 2. Comparisons of the number of recorded behaviours performed by the greater rheas during the three phases of the study: baseline, enrichment and post-enrichment (mean \pm standard erros; $D F=2 ; N=30 ; a=0.05$ ).

\begin{tabular}{cccccc}
\hline Behaviour & Baseline & Enrichment & $\begin{array}{c}\text { Post- } \\
\text { enrichment }\end{array}$ & Friedman & P-value \\
\hline AL & $25.93 \pm 1.81^{\mathrm{a}}$ & $54.76 \pm 3.63^{\mathrm{b}}$ & $73.76 \pm 5.20^{\mathrm{b}}$ & 44.60 & $<0.01^{*}$ \\
IN & $14.83 \pm 2.68^{\mathrm{a}}$ & $35.00 \pm 8.66^{\mathrm{a}}$ & $63.20 \pm 7.42^{\mathrm{b}}$ & 14.71 & $<0.01^{*}$ \\
EAT & $4.30 \pm 0.77^{\mathrm{a}}$ & $4.56 \pm 1.08^{\mathrm{a}}$ & $13.43 \pm 12.19^{\mathrm{b}}$ & 9.86 & $<0.01^{*}$ \\
DRI & $3.36 \pm 0.70$ & $1.93 \pm 0.59^{\mathrm{a}}$ & $7.70 \pm 1.48^{\mathrm{b}}$ & 14.01 & $<0.01^{*}$ \\
RUN & $1.13 \pm 0.34^{\mathrm{a}}$ & $0.70 \pm 0.33^{\mathrm{a}}$ & $0.03 \pm 0.03^{\mathrm{b}}$ & 5.71 & $0.05^{*}$ \\
FIGH & $0.00 \pm 0.00$ & $0.10 \pm 0.07$ & $0.06 \pm 0.06$ & 0.15 & 0.92 \\
PREE & $4.33 \pm 1.04^{\mathrm{a}}$ & $10.93 \pm 2.27^{\mathrm{a}}$ & $25.36 \pm 3.03^{\mathrm{b}}$ & 25.01 & $<0.01^{*}$ \\
ATTA & $0.83 \pm 0.34$ & $0.10 \pm 0.07$ & $1.70 \pm 0.79$ & 4.01 & 0.13 \\
WAAL & $0.33 \pm 0.09$ & $0.06 \pm 0.04$ & $0.36 \pm 0.13$ & 2.11 & 0.34 \\
ESC & $0.03 \pm 0.03$ & $0.56 \pm 0.20$ & $0.16 \pm 0.08$ & 2.06 & 0.35 \\
PEC & $0.20 \pm 0.10^{\mathrm{a}}$ & $0.03 \pm 0.03^{\mathrm{a}}$ & $3.70 \pm 0.62^{\mathrm{b}}$ & 30.35 & $<0.01^{*}$ \\
BATH & $0.50 \pm 0.24$ & $0.66 \pm 0.31$ & $1.20 \pm 0.38$ & 1.11 & 0.57 \\
DFU & $0.36 \pm 0.08$ & $0.60 \pm 0.14$ & $0.73 \pm 0.15$ & 1.61 & 0.44 \\
OTH & $0.40 \pm 0.14$ & $0.63 \pm 0.24$ & $0.86 \pm 0.23$ & 4.11 & 0.12 \\
NV & $0.56 \pm 0.17$ & $0.30 \pm 0.13$ & $0.00 \pm 0.00$ & 4.26 & 0.11 \\
\hline
\end{tabular}

* = results that differed statistically; different superscript letters represent differences between phases according to Dunn's post-hoc tests. AL = alert, IN = inactive, EAT = eating, DRI = drinking water, RUN = running, FIGH = fighting, PREE = preening, ATTA = attacking keeper, WAAL = walking alert, ESC = escaping behaviour, $\mathrm{PEC}=$ pecking, $\mathrm{BATH}=$ dust bathing, DFU = defecating/urinating, $\mathrm{OTH}=$ other behaviours, $\mathrm{NV}=$ not visible.

\section{Walking}

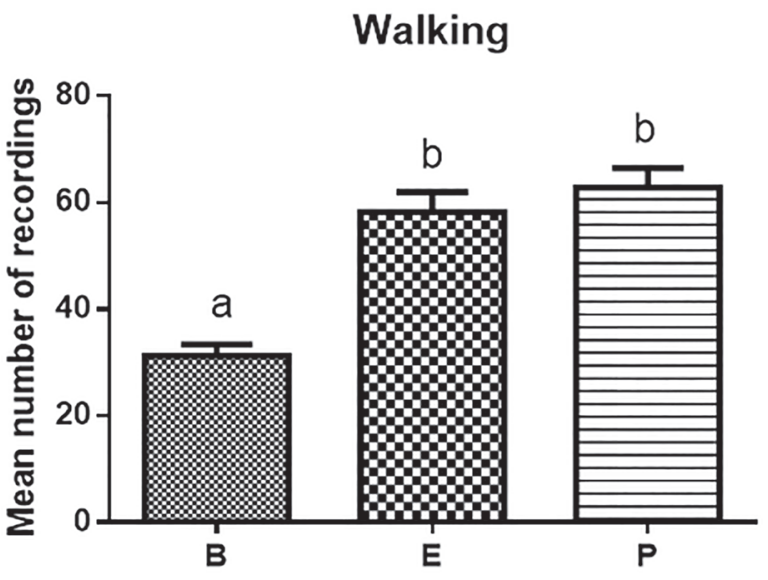

Eating feces

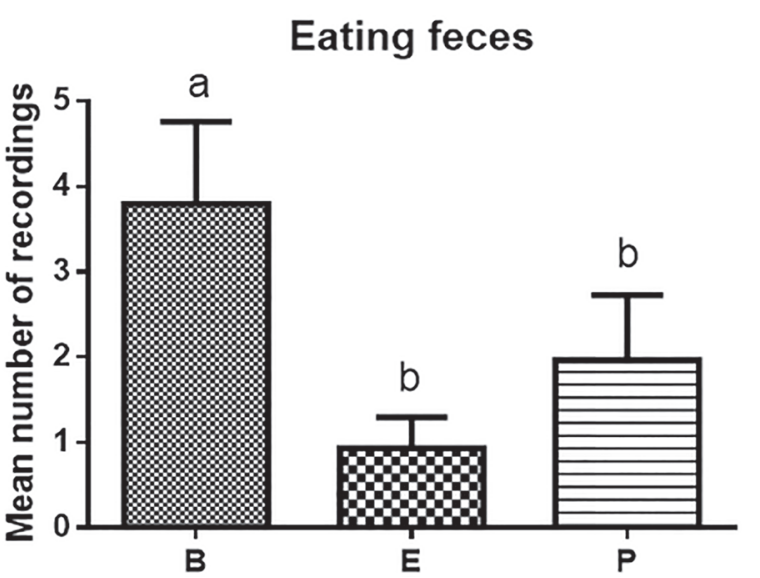

environmental enrichment was used to stimulate foraging in animals. Stimulating foraging makes animals spend more time looking for food, consequently, there is greater exploration of the enclosure and the expression of abnormal behaviours is reduced or even extinguished, improving animal welfare (Shepherdson et al., 1990; Carlstead et al., 1991; Shepherdson et al., 1993; Boinski et al., 1999; Young, 2003; Cummings et al., 2007). Furthermore, wild greater rheas are known to walk long distances foraging (Azevedo et al., 2010), thus, scattering fruits around an enclosure simulate forging in nature.

GCM levels of male greater rheas decreased significantly during the enrichment phase. In the post-enrichment phase, GCM levels showed a decrease, though not significant, proving the effectiveness of environmental enrichment in decreasing stress in the long-term. Other studies involving environmental enrichment with faecal hormone analysis found the same result and also confirmed the success of enrichment in improving animal welfare (Boinski et al., 1999; Poessel et al., 2011; Belz et al., 2003; Benaroya-Milshtein et al., 2004).

The long-term effects of environmental enrichment can be related to changes in the brain (more neurons and synapsis, more glia cells, more neurotransmissor production, more gene expression etc., which enhances cognition and memory (Rampon et al., 2000; van
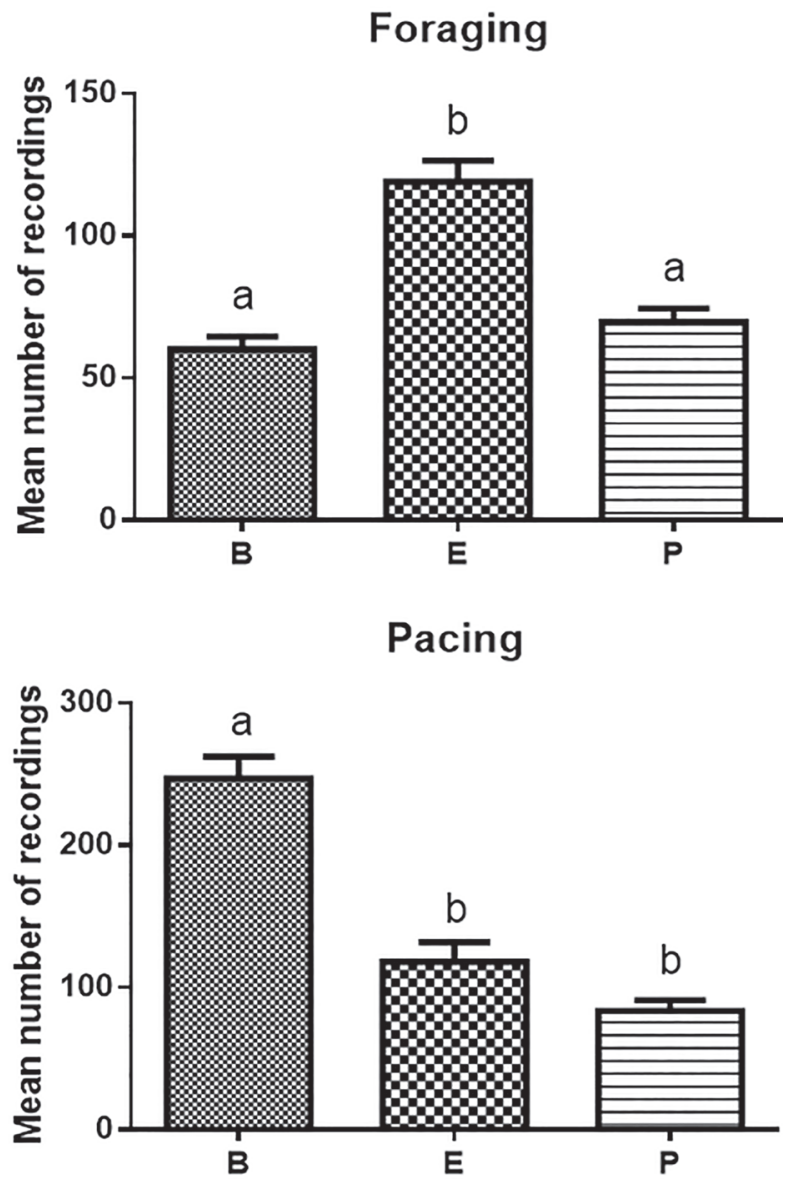

Figure 2. Exhibition of behaviours "walking" ( $F=31.51, p<0.01, N=30, D F=2)$, "foraging" $(F=28.31, p<0.01, N=30, D F=2)$, "eating faeces" ( $F=6.01$, $\mathrm{p}=0.05, \mathrm{~N}=30, \mathrm{DF}=2)$ and "pacing" $(F=32.06, \mathrm{p}<0.01, \mathrm{~N}=30, \mathrm{DF}=2)$ by greater rheas in the three phases of a food enrichment study in the enclosure at the Belo Horizonte Z00, Brazil. Different letters represent treatments that significantly differed between each other. $b=$ baseline; $\mathrm{e}=$ enrichment; $p=$ post-enrichment. 


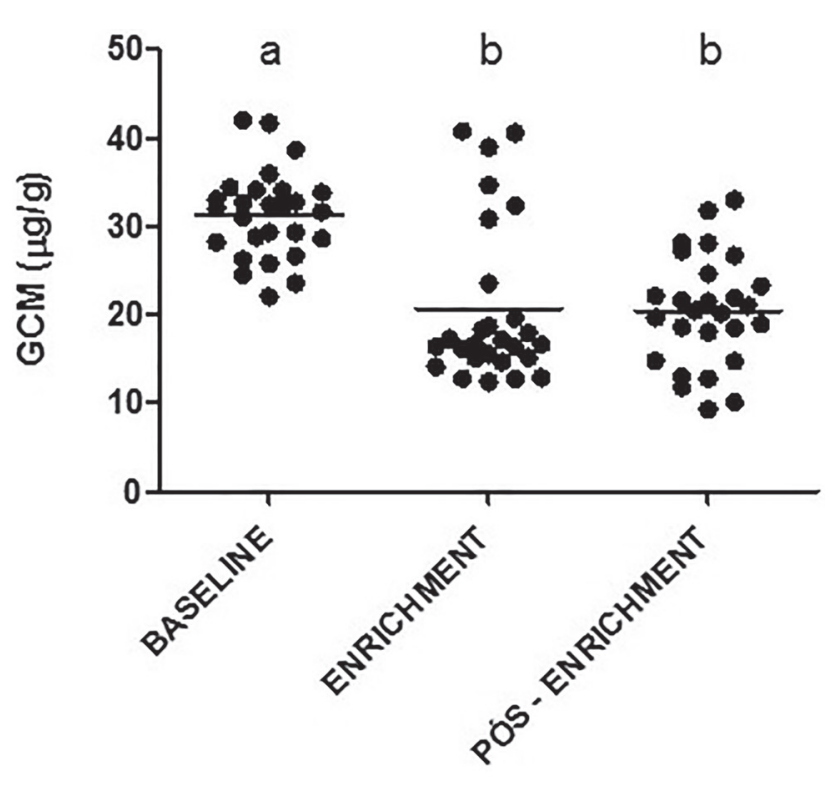

Phase

Figure 3. GCM concentrations for greater rheas during a food enrichment study at the Belo Horizonte Z0o, Brazil ( $F=22.51 ; \mathrm{p}<0.01 ; \mathrm{N}=27$; $\mathrm{df}=2$ ). Different letters represents phases that differed significantly between each other.

Praag et al., 2000). Besides, the food-based enrichment used in the present study probably continues to elicit the foraging behaviours even after the end of the enrichment phase, since the shopped fruits were scattered through the enclosure. Since the fruits were not easily found by the greater rheas (they mixed with leaves on the ground), male greater rheas keep foraging over long periods of time (days after the end of the enrichment phase). The time enrichment was offered to the birds may have been short, avoiding birds' habituation. In a study with Clark's nutcrackers (Nucifraga columbiana), corticosterone levels in the feathers diminished after the end of short-term enrichment (10 days), but not after long-term enrichment (3 months) (Fairhust et al., 2011).

The correlation between GCM and pacing behaviour in the enrichment phase was significant and positive. Vasconcellos et al. (2009) found the same result in maned wolves (Chrysocyon brachyurus), a positive correlation between GCM levels and pacing behaviour. An enrichment study with captive felids also showed a positive correlation between glucocorticoid and abnormal pacing behaviour (Galvez, 2008). Although GCM presents a circadian rhythm of secretion, being more secreted during periods of activity (Chung et al., 2011), in the present study this correlation was not observed; that is, although the production of GCM increased during male greater rheas' activity periods, it only increased significantly when pacing was being exhibited. However, since we only collected on fecal sample per day, how GCM varies in the greater rheas' day (circadian rhythm) still needs to be investigated.

After the enrichment phase, male greater rheas spent more time foraging, walking, alert and eating from the feeders instead of exhibiting the abnormal behaviour

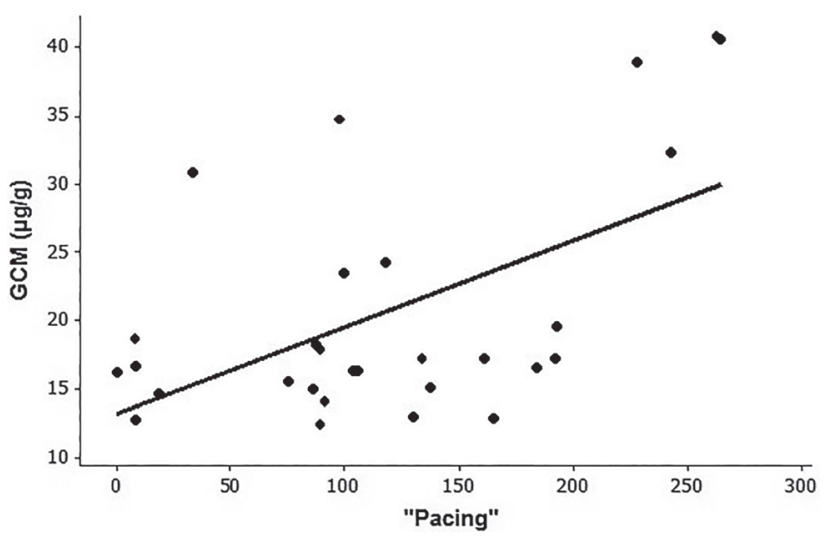

Figure 4. Spearman correlation between daily faecal glucocorticoid metabolite concentration and daily number of recordings of "pacing" behaviour of greater rheas during the enrichment phase in the enclosure at the Belo Horizonte Z00, Brazil $\left(r_{s}=0.418 ; p<0.05, N=29 ; d f=2\right)$.

pacing. This result corroborates the idea that the benefits of environmental enrichment are long-lasting. $\mathrm{BH}$ Zoo is now using scattered food as environmental enrichment for greater rheas, and new items are being tested (e.g., hanging fruits). Larger and more naturalistic enclosures, with many planted fruiting trees should be planned by the $\mathrm{BH}$ Zoo managers and keepers to improve greater rhea welfare. A study with more rhea individuals should be conducted to evaluate if the results found in this pilot study are generalisable. If so, environmental enrichment should be routinely used in greater rheas' husbandry. Besides, the influence of other environmental variables on greater rheas' stress, like temperature and humidity, should be also evaluated to make this methodology more reliable.

\section{Animal Welfare Implications and Conclusions}

Food-based environmental enrichment is an effective tool to increase male greater rhea welfare, since it reduced not only the expression of abnormal behaviours but also reduced GCM levels. Furthermore environmental enrichment effects appeared to be long-lasting and continued for at least 30 days after the enrichment had stopped. The results presented here indicate that environmental enrichment reduced male greater rheas' stress; thus, if this technique is applied to farmed greater rheas, it may increase their productivity (increasing the profitability of such business). Thus, institutions that hold greater rheas in captivity should be providing food-based enrichment as part of their animal care program.

\section{ACKNOWLEDGMENTS}

Authors would like to thank all the $\mathrm{BH}$ Zoo staff for the authorization to conduct the study, especialy Angela Faggioli, João Bosco Ferraz, Amarildo Pedrosa and Carlyle Mendes Coelho. CSA would like to thank CAPES, FAPEMIG, CEMIG and Vallourec for finantial support. 


\section{REFERENCES}

Altmann, J. 1974. Observational study of behaviour: sampling methods. Behaviour, 49(3-4): 227-267.

Azevedo, C.S. \& Young, R.J. 2006. Behavioural responses of captive-born greater rheas Rhea americana Linnaeus (Rheiformes, Rheidae) submitted to antipredator training. Revista Brasileira de Zoologia, 23(1): 186-193. DOI

Azevedo, C.S.; Ferraz, J.B.; Tinoco, H.P.; Young, R.J. \& Rodrigues, M. 2010. Time-activity budget of greater rheas (Rhea americana, Aves) on a human-disturbed area: the role of habitat, time of the day, season and group size. Acta Ethologica, 13: 109-117. DOI

Azevedo, C.S.; Lima, M.F.F.; Silva, V.C.A.; Young, R.J. \& Rodrigues, M. 2012a. Visitor influence on the behaviour of captive greater rheas (Rhea americana, Rheidae Aves). Journal of Applied Animal Welfare Science, 15: 113-125. DOI

Azevedo, C.S.; Young, R.J. \& Rodrigues, M. 2012b. Failure of captive-born greater rheas (Rhea Americana, Rheidae, Aves) to discriminate between predator and nonpredator models. Acta Ethologica, 15: 179-185. DOI

Azevedo, C.S.; Lima, M.F.F.; Cipreste, C.F.; Young, R.J. \& Rodrigues, M. 2013a. Using environmental enrichment to reduce the expression of abnormal behaviours in Greater rhea Rhea americana at Belo Horizonte Zoo. International Zoo Yearbook, 47: 163-170. D0I

Azevedo, C.S.; Silva, M.C.; Teixeira, T.P.; Young, R.J.; Garcia, Q.S. \& Rodrigues, M. 2013b. Effect of passage through the gut of Greater Rheas on the germination of seeds of plants of cerrado and caatinga grasslands. Emu, 113: 177-182. DOI

Belz, E.E.; Kennell, J.S.; Czambel, R.K.; Rubin, R.T. \& Rhodes, M.E. 2003. Environmental enrichment lowers stress-responsive hormones in singly housed male and female rats. Pharmacoogy Biochemistry and Behaviour, 76: 481-486. DOl

Benaroya-Milshtein, N.; Hollander, N.; Apter, A.; Kukulansky, T.; Raz, N.; Wilf, A.; Yaniv, I. \& Pick, C.G. 2004. Environmental enrichment in mice decreases anxiety, attenuates stress responses and enhances natural killer cell activity. European Journal of Neuroscience, 20: 1341-1347. D0I

Berbare, P.E.B. 2004. Avaliação longitudinal das concentrações de esteróides fecais em fêmeas de gato-mourisco (Herpailurus yagoauroundi, Lacépède, 1809). (Master Dissertation). São Paulo, Universidade de São Paulo.

Boinski, S.; Swing, S.P.; Gross, T.S. \& Davis, J.K. 1999. Environmental enrichment of brown capuchins (Cebus apella): behavioural and plasma and faecal cortisol measures of effectiveness. American Journal of Primatology, 48(1): 49-68. DOI

Broom, D.M. \& Molento, C.F.M. 2004. Bem-estar animal: conceito e questões relacionadas. Archives of Veterinary Science, 9: 1-11.

Brown, J.L.; Terio, K.A. \& Graham, L.H. 1996. Faecal androgen metabolite analysis for noninvasive monitoring of testicular steroidogenic activity in felids. Zoo Biology, 15: 425-434. DOI

Carlstead, K.; Seidensticker, J. \& Baldwin, R. 1991. Environmental enrichment for zoo bears. Zoo Biology, 10: 3-16. D0l

Christensen, J.W. \& Nielsen, B.L. 2004. Environmental Enrichment for Ostrich, Struthio camelus, chicks. Animal Welfare, 13: 119-124.

Chung, S.; Son, G.H.\& Kim, K. 2011. Circadian rhythm of adrenal glucocorticoid: its regulation and clinical implications. Biochimica et Byophisica Acta, 1812(5):581-591. DOI

Clark, F.E. \& Melfi, V.A. 2012. Environmental enrichment for a mixed-species nocturnal mammal exhibit. Zoo Biology, 31:397-413. D01

Cubas, Z.S.; Silva, J.C.R. \& Catão-Dias, J.L. 2007. Tratado de animais silvestres: medicina veterinária. São Paulo, Editora Roca.

Cummings, D.; Brown, J.L.; Rodden, M.D. \& Songsasen, N. 2007. Behavioural and physiologic responses to environmental enrichment in the maned wolf (Chrysocyon brachyurus). Zoo Biology, 26: 331-343. D01
Dani, S. 1993. A ema Rhea americana: biologia, manejo e conservação. Belo Horizonte, Fundação Acangaú.

Della Costa, N.S.; Lèche, A.; Guzmán, D.A.; Navarro, J.L.; Marin, R.H. \& Martella, M.B. 2013. Behavioural responses to short-term transport in male and female Greater Rheas (Rhea americana) reared in captivity. Poultry Science, 92(4): 849-857. D01

Dias, E.; Martins, A.; Pessutti, C. \& Barrella, W. 2011. Enriquecimento Ambiental no recinto do mutum-de-penacho (Crax fasciolata) do Parque Zoológico Municipal "Quinzinho de Barros" (PZMQB), Sorocaba, SP. Revista Eletrônica de Biologia, 3: 20-38.

Fairhust, G.D.; Frey, M.D.; Reichert, J.F.; Szelest, I.; Kelly, D.M. \& Bortolotti, G.R. 2011. Does environmental enrichment reduce stress? An integrated measure of corticosterone from feathers provides a novel perspective. Plos One, 6: e17663. D0I

Galvez, D. 2008. Efecto del enriquecimiento ambiental sobre el bienestar de tres espécies de felinos mexicanos en peligro de extinción (ocelote, margay y jaguarundi) mantenidos en cautiverio. (Doctoral Thesis). Universidad Nacional de Mexico, Mexico City.

Gebregeziabhear, E. \& Ameha, N. 2015. The effect of stress on productivity of animals: a review. Journal of Biology, Agriculture and Healthcare, 5: 165-172.

Glatz, P.; Lunam, C. \& Malecki, I. 2011. The welfare of farmed ratites. Berlin, Springer.

Hosken, F.M. \& Silveira, A.C. 2003. Criação de Emas. Viçosa, Editora Aprenda Fácil.

International Union for Conservation of Nature and Natural Resources (IUCN). 2018. IUCN Red List of Threatened Species. Version 2018.1. http://www. iucnredlist.org. Download in: 16/05/2018.

Kelling, J. \& Jensen, P. 2009. Abnormal Behaviour, Stress and Welfare. In: Jensen, P. (Ed.). The Ethology of Domestic Animals. Wallingford, CABI. p. 85-101.

Lèche, A.; Busso, J.M.; Navarro, J.L.; Hansen, C.; Marin, R.H. \& Martella, M.B. 2011. Non-invasive monitoring of adrenocortical activity in Greater rhea (Rhea americana) by faecal glucocorticoid analysis. Journal of Ornithology, 152: 839-847. DOI

Lèche, A.; Busso, J.M.; Navarro, J.L.; Hansen, C.; Marin, R.H. \& Martella, M.B. 2009. Physiological stress in captive Greater rheas (Rhea americana): highly sensitive plasma corticosterone response to an ACTH challenge. General and Comparative Endocrinology, 162: 188-191. D0I

Lèche, A.;Della Costa, N.S.; Hansen, C.; Navarro, J.L.; Marin, R.H.\& Martella, M.B. 2013. Corticosterone stress response of Greater Rhea (Rhea americana) during short-term road transport. Poulty Science, 92: 60-63. D0I

Meehan, C.J.; Garner, J.P. \& Mench, J.A. 2004. Environmental enrichment and development of cage stereotypy in Orange-winged Amazon Parrots (Amazona amazonica). Developmental Psychobiology, 44: 209-218. D0I

Meehan, C.J.; Millam, J.R. \& Mench, J.A. 2003. Foraging opportunity and increased physical complexity both prevent and reduce psychogenic feather picking by young Amazon parrots. Applied Animal Behaviour Science, 80: 71-85. D0I

Moberg, G.P. \& Mench, J.A. 2000. The Biology of Animal Stress: basic principles and implications for animal welfare. Wallingford, CAB International.

Möstl, E. \& Palme, R. 2009. Measuring faecal steroid metabolites with enzyme immunoassays (EIA) on microtitre plates using biotinylated steroids as labels. Viena, Protocol Department of Biomedical Sciences, University of Veterinary Medicine.

Navarro, J.L. \& Martela, M.B. 2002. Reproductivity and raising of Greater rhea (Rhea americana) and Lesser rhea (Pterocnemia pennata) - a review. Archiv fur Geflugelkunde, 66: 124-132.

Palme, R.; Touma, C.; Arias, N.; Dominchin, M.F. \& Lepschy, M. 2013. Steroid extraction: get the best out of faecal samples. Wiener Tierärztliche Monatsschrift - Veterinary Medicine Austria, 100: 238-246. 
Poessel, S.A.; Biggins, D.E.; Santymire, R.M.; Livieri, T.M.; Crooks, K.R. \& Angeloni, A. 2011. Environmental enrichment affects adrenocortical stress responses in the endangered black-footed ferret. General and Comparative Endocrinology, 172: 526-533. D01

Rampon, C.; Jiang, C.H.; Dong, H.; Tang, Y.P.; Lockhart, D.J.; Schultz, P.G.; Tsien, J.Z. \& Hu, Y. 2000. Effects of environmental enrichment on gene expression in the brain. Proceedings of the National Academy of Sciences, 97: 12880-12884. DOI

Reboita, M.S.; Rodrigues, M.; Silva, L.F. \& Alves, M.A. 2015. Aspectos climáticos do Estado de Minas Gerais. Revista Brasileira de Climatologia, 17: 206-226. DOI

Redbo, I. 1993. Stereotypies and cortisol secretion in heifers subjected to tethering. Applied Animal Behaviour Science, 38: 213-225. D0I

Renison, D.; Valladares, G. \& Martella, M.B. 2010. The effect of passage through the gut of the Greater Rhea (Rhea americana) on germination of tree seeds: implications for forest restoration. Emu, 110: 125-131. D0I

Salak-Johnson, J.L.; McGlone, J.J.; Whisnant, C.S.; Norman, R.L. \& Kraeling, R.R. 1997. Intracerebroventricular porcine corticotropin-releasing hormone and cortisol effects on pig immune measures and behaviour. Physiology and Behaviour, 61: 15-23. DOI

Shepherdson, D.J.; Brownback, T. \& Tinkler, D. 1990. Putting the wild back into zoos: enriching the zoo environment. Applied Animal Behaviour Science, 28: 300 . DOI

Shepherdson, D.J.; Carlstead, K.; Mellen, J.D. \& Seidensticker, J. 1993. The influence of food presentation on the behaviour of small cats in confined environments. Zoo Biology, 12: 203-16. DOI
Shepherdson, D.J.; Mellen, J.D. \& Hutchins, M. 1998. Second Nature: environmental enrichment for captive animal. Washington, Smithsonian Institution Press.

Sick, H. 1997. Ornitologia Brasileira. Rio de Janeiro, Editora Nova Fronteira.

Silva, J.B.G. 2001. Rheacultura: criação de emas. Curitiba, Editora Agropecuária. Touma, C. \& Palme, R. 2005. Measuring faecal glucocorticoid metabolites in mammals and birds: the importance of validation. Annals of the New York Academy of Science, 1046: 54-74. DOI

van Praag, H.; Kempermann, G. \& Gage, F.H. 2000. Neural consequences of environmental enrichment. Nature Reviews, 1: 191-198. DOI

Vasconcellos, A.S.; Guimarães, M.A.B.V.; Oliveira, C.A.; Pizzutto, C.S. \& Ades, C. 2009. Environmental Enrichment for Maned Wolves: group and individual effects. Animal Welfare, 18: 289-300.

Viau, P. 2003. Estudo da função ovariana em fêmeas de onça-pintada (Panthera onca, Linnaeus, 1758) mantidas em cativeiro, por meio da extração e quantificação de esteróides fecais. (Master Dissertation), Universidade de São Paulo, São Paulo.

Vincent, I.C. \& Michell, A.R. 1992. Comparison of cortisol concentrations in saliva and plasma of dogs. Research in Veterinary Science, 53: 342-345. DOI

Young, R.J. 2003. Environmental Enrichment for Captive Animals. Oxford, Blackwell Publishing.

Zar, J.H. 2010. Biostatistical analysis. 5. ed. New Jersey, Prentice Hall/Pearson. 